\title{
Preskryptywny charakter internalizacji aksjologicznej jako podstawa stosunku człowieka do lasu jako ekowartości
}

\author{
Katarzyna kukaszewska \\ Katedra Filozofii Moralności i Etyki Globalnej \\ Akademia Pedagogiki Specjalnej im. Marii Grzegorzewskiej w Warszawie, ul. Szczęśliwicka 40, 02-353 Warszawa \\ klukaszewska@aps.edu.pl•ORCID 0000-0002-3986-7731
}

\begin{abstract}
Strzeszczenie
Internalizacja, czyli uwewnętrznianie treści o charakterze aksjologicznym, jest zbieżna z zyskiwaniem umiejętności o wyższym standardzie moralnym. Źródłem odpowiedzialności staje się wówczas po prostu obiektywna wartość. Uwewnętrznienie aksjologicznych wymagań płynących od ekowartości jest najskuteczniejszym rodzajem zobowiązania, ponieważ ma ono charakter preskryptywny: obietnicy danej sobie nie można nie dotrzymać bez poczucia straty danego słowa. W tym kontekście zinternalizowana ekowartość preskryptywnie oddziałuje na człowieka, którego odpowiedzialność jest tym głębsza, im silniej sama wartość jest uwewnętrzniona. Stąd też las, jako przykład ekowartości, przyjmuje dla człowieka charakter bezwzględny tylko w przypadku internalizacji preskryptywnej, gdy źródłem powinności jest nie tyle konieczność ekologiczna, ile wartość autoteliczna.
\end{abstract}

\section{Słowa klucze}

wartość, wartość ekologiczna, internalizacja preskryptywna, aksjologia

\section{Wprowadzenie}

W obliczu rozpatrywania ekologicznej ważności oraz znaczenia z aksjologicznej perspektywy można wprost stwierdzić - las jest wartością. Wartością, bez ochrony której trudno jest mówić o postępie w zdolnościach moralnych współczesnego człowieka. Uciekając od miejsc przesyconych bytnością masową, poszukując dystansu i perspektywy, łaknąc widoku regularnej zieleni - wracamy w przestrzeń możliwie jak najbardziej do lasu zbliżoną. Zadaniem niniejszego artykułu zamierzam jednak uczynić nie tyle analizę tęsknej dążności do leśnej estetyki, coraz częściej i tak „zdeficytowanej” we współczesnym otoczeniu człowieka, ile przedstawienie lasu jako wartości i umieszczenie tej wartości w perspektywie aksjologicznego procesu internalizacji. Bowiem „istnieje pewien proces rozwoju wewnętrznego, któremu poddany jest w większym lub mniejszym stopniu każdy człowiek, prowadzący do pewnego obrazu rzeczywistości, obrazu związanego z pewnym sensem oraz realizacją wartości. Prowadzi to do określonego sposobu pojmowania celu i sensu istnienia, z którego, gdy zostanie zaakceptowany, wynika system wartości. System ten staje się punktem odniesienia przy podejmowaniu różnych działań, co nie oznacza, 
iż został sformułowany w sposób werbalny. Może to być po prostu rodzaj wewnętrznego ukierunkowania, który w praktyce odgrywa większą rolę niż wszelkie rozumowanie czy świadome kalkulacje, będące często tylko próbą zracjonalizowania dokonanego już wyboru" (Stacewicz 1993: 83). To nie od wiedzy ekologicznej bowiem, ale świadomości moralnej zależy stosunek człowieka do ekowartości. Opieka nad wartością, jeśli ma mieć charakter trwały, powinna przyjmować postać troski o dobro jako takie, obiektywne, wspólne; ten zaś rodzaj określania ważności wartości jest przejawem rozróżniania wiedzy o wartościach od uwewnętrznienia (internalizacji) wartości, czyli rozumienia ich formy. W procesie wartościowań bowiem „w wartościach [...] nie zmienia się forma [...], jedynie zmienia się ich treść. Zmienność zaś treści nie świadczy o relatywizmie wartości [...]. Zmienność ta dotyczy ujęcia i polega na ułomności poznania człowieka, świadczy o relatywizmie ludzi, a nie wartości" (Kunowski 2003: 28). Dlatego też umiejętność wartościowania na poziomie tejże formy wartości przyjmuje dla kondycji moralnej człowieka zupełnie inną perspektywę, która unaoczniając tę znaczącą różnicę, preskryptywnie wręcz (a więc zalecająco i z jednoznaczną presją wywieraną na świadomość) poleca do wyboru zachowanie chroniące takie rozumienie wartości, które stanowi o jej niezmiennym charakterze. Ekowartość jest aksjologicznie wiarygodnie chroniona tylko wówczas, gdy wyznacznikiem zachowań wobec tejże wartości jest osobista internalizacja aksjologiczna jednostki. Człowiek może chronić wartość z wielu powodów; jednym z najważniejszych i najautentyczniejszych jest jego osobisty stosunek do tego, czym jest axia jako taka - gdy stanowi ona sedno nakazującego, preskryptywnego rodzaju presji, jaką człowiek przypilnowuje sam siebie.

Przejawy mniejszej lub większej troski o to, czym jest las i jaki jest, można odnaleźć w czasach bardzo dawnych: „Hammurabi (1792-175o p.n.e.) powołał np. leśnika, który miał nadzór nad lasami, w Libanie (ok. 450 r. p.n.e.), Artakserkses I ograniczył wycinanie cedrów, w Grecji, w czasach Homera gaje były strzeżone przez powołane do tego osoby. W Rzymie, pomimo niszczenia lasów na dużą skalę, nie brak było głosów w ich obronie, np. Cyceron stwierdził, że niszczenie lasów przynosi wielką szkodę dla dobra ogólnego. Pliniusz Starszy ostrzegał przed zniszczeniem lasów, szczególnie wylesieniem stoków górskich, zaznaczał, że las stanowi cenne bogactwo dla człowieka. W średniowieczu i nowożytności świadomość odpowiedzialności za lasy jest już bardziej rozwinięta. Najczęściej odpowiedzialność miała charakter kodeksowy. Jednak wskutek obserwacji zagrożeń w przyrodzie pod koniec XIX wieku przybiera ona formę pozaprawną" (Zięba 2002: 201), wewnętrzną, osobiście świadczącą o kompetencjach moralnych jednostki. Przesunięcie nastąpiło (lub raczej należałoby powiedzieć: wciąż następować powinno) z perspektywy odgórnej w stronę trwalszych ową preskyptywnością przypilnowań osobistych, moralnych zobowiązań wewnętrznych, powodowanych presją zrozumienia ważności formy wartości samej w sobie, jako takiej. „Rozpoznawanie wartości może być uznane za pierwsze stadium ich rozumienia. W tym znaczeniu jest ich przedłużeniem" (Frączek 2002: 48). Niemniej to dzięki procesowi internalizacji, czyli uwewnętrznienia przez człowieka, wartości stają się z nim spójną częścią. „Wartości tkwiące w przyrodzie odczytuje człowiek i to na nim spoczywa odpowiedzialność za jego czyny, których konsekwencją są perturbacje w systemach przyrody" (Zięba 2002: 199). Dlatego, iż to preskryptywny charakter uwewnętrzniania treści o charakterze aksjologicznym w sposób trwały wpływa na stosunek człowieka do świata przyrody, czyli świata wartości ekologicznych.

\section{Wartości ekologiczne}

Wartości ekologiczne podlegają procesowi internalizacji na takiej samej zasadzie, jak wszystkie wartości w ogóle. „Sam termin internalizacja został po raz pierwszy użyty w pracy F.C. Bartletta Thinking, wydanej 
w 1958 r. w Londynie. W pracy tej Bartlett, posługując się wynikami badań eksperymentalnych, udowodnił względnie dużą niezależność procesów myślowych od czynności zewnętrznych. (motorycznych). W ten sposób doszedł do wniosku, że informacje, które posiada człowiek - muszą podlegać wewnętrznej stratyfikacji i w zależności od stopnia ich akceptacji wpływają na zachowanie się człowieka. Zjawisko to nazwał internalizacją (od łac. internus - wewnętrzny)" (Konstańczak 2001: 86-87). Proces zakorzeniania treści o charakterze aksjologicznym jest więc zbieżny z zyskiwaniem umiejętności o wyższym standardzie moralnym, kiedy to źródła odpowiedzialności moralnej zaczynamy szukać w samej tej wartości, a nie poza nią. Jeżeli źródłem powinności moralnej staje się sama wartość, to sankcje moralne zostają przeniesione w przestrzeń osobistą, w głąb sumienia moralnego. Proces ten, który nazywam internalizacją, eksponuje zasadność postępowania zgodnie z powinnością, do której to odsyłają normy, ale której faktycznym źródłem jest właśnie wartość. Internalizacja to najskuteczniejszy sposób kształtowania postawy wobec tego, co ważne, ponieważ zakorzenia sens, który człowiek potrafi później trafnie odnaleźć w świecie. Człowiek moralnie dojrzały kieruje się wówczas autotelicznym charakterem wartości, jako źródłem pobudek moralnych. Trudno jest tę autoteliczność odkryć dla samego siebie i sobie ją wytłumaczyć. Jednak proces internalizacji aksjologicznej pozwala przyjąć ją w sposób niebezkrytyczny, z większą świadomością, jak również z większą odpowiedzialnością. Internalizacja ekowartości jest tego dobrym przykładem, pokazuje bowiem, jak axia może łączyć człowieka w moralnym zobowiązaniu ze światem środowiska naturalnego. Uwewnętrzniona ekowartość staje się wtedy źródłem wszelkich powodów, dla których decydujemy się na podjęcie działań w przestrzeni moralnej odpowiedzialności za świat przyrody. Trudno odpowiadać na wymagania, których nie odczytujemy jako własne. Gdy zaś „sami z siebie”, a dokładniej ze zinternalizowanych wartości, generujemy zobowiązania, są one dla nas bardziej czytelne, gdyż sami je nie tylko znamy, lecz także dobrze rozumiemy. Zrozumienie wartości pozwala podlegać określonym wymaganiom refleksyjnie, $\mathrm{z}$ namysłem, ze świadomością. Nie potrzebujemy wtedy szukać poza sobą czynników motywujących do ochrony jakiejś wartości - skoro jest „nasza”, przyswojona, pozostaje dla nas czytelna oraz często czytana; nabieramy wprawy w posługiwaniu się odpowiedziami moralnymi, czyli odpowiedzialnością. „W swoim źródłosłowie pojęcie odpowiedzialności odwołuje się do [...] swoiście ludzkiej czynności, jaką jest mowa, a konkretnie - jej forma, którą jest odpowiadanie" (Ciążela 2006: 30); odpowiedzialność jest rodzajem dawania odpowiedzi - odpowiadam, gdy odpowiedź znam, ale mogę ją znać, pomimo że jej nie rozumiem. Regularne zaś czytanie wartości pozwala zyskać wprawę w odpowiadaniu nie tyle na oczekiwania, co na wymagania płynące od wartości uwewnętrznionej. „Antonie Saint-Exupery pisał, że być człowiekiem, to być odpowiedzialnym. Człowiek odpowiada z tej racji, że jest człowiekiem, «jestem, więc odpowiadam»" (Zięba 2002: 214); na tym polega sens odpowiedzialności indywidualnej. Odpowiadam w obliczu aksjologicznej istotności, czyli wartości. Ekowartości zaś są szczególnie związane z osobistym zobowiązaniem człowieka do postępowania odpowiedzialnego - sam ten wymóg jest bowiem ulokowany po stronie tejże wartości, która jest ona nie tylko ekologicznie ważna, ale przede wszystkim jest po prostu wartością, w sensie aksjologicznej istotności oraz pod względem swej formy niezmiennej. W takim ujęciu tym, co spaja moralne zobowiązanie i wartość ekologiczną, jest internalizacja - nie można procesu tego odwrócić bez konsekwencji ze strony subiektywnego, własnego miernika czynów, jakim jest sumienie. Dlatego też sądzę, że uwewnętrznienie aksjologicznych wymagań płynących od ekowartości jest najskuteczniejszym rodzajem zobowiązania do ochrony wartości, jaką jest las, ponieważ jest to zobowiązanie o charakterze preskryptywnym: w tym 
sensie, obietnicy danej sobie nie można nie dotrzymać bez poczucia straty danego słowa. W tym kontekście zinternalizowana ekowartość preskryptywnie oddziałuje na człowieka, którego odpowiedzialność jest tym głębsza, im silniej sama wartość jest uwewnętrzniona.

\section{Internalizacja aksjologiczna}

Jeżeli wartość została zinternalizowana, tzn. że jej walor sensotwórczy został zrozumiany, przyswojony i wewnętrznie uznany za imperatywny, zobowiązujący, określający powinność. Uwewnętrznianie treści aksjologicznych odbywa się poprzez regularny kontakt z wartościami, które stają się nośnikami sensów - sensów szukanych jako konstytucje wszystkich działań zorientowanych na to, co przynosi znaczenie, co ma walor i celowość, określoną istotność. „Na pytanie, jak aktualizuje się funkcja kształcenia postępowania przez wartość, odpowiadam, że musi istnieć jakiś «transformator», wywołujący pewną czynność, w wyniku której nastąpi ukształtowanie się postępowania. Całokształt tego stosunku, czynności, przyczyn i skutków, łączący wartości z postepowaniem człowieka, nazywamy introcepcją wartości" (Kunowski 2003: 47), przenoszeniem do wewnątrz i odczuwaniem od środka. Nadawanie sensu aksjologicznego wiąże się $\mathrm{z}$ uwewnętrznioną potrzebą bycia zorientowanym na wartości. Rola tej wewnętrznej presji jest ogromna - jeżeli axia jest źródłem zobowiązań moralnych, autonomia działań jest tym większa, ponieważ wewnętrzna samodyscyplina zmniejsza konieczność presji z zewnątrz. „Przyjmuję, że internalizacja to uniezależnienie szeroko rozumianego zachowania człowieka - od zewnętrznych wzmocnień” (Konstańczak 2001: 87). Stąd znaczenie internalizacji stanowi sedno działań moralnych - tych można podejmować się z wielu różnych powodów, jednak trwałość owemu zorientowaniu na wartość gwarantuje wewnętrzne przekonanie i autonomiczna decyzja, by autotelicznie pojętej wartości chcieć służyć własnymi wyborami moralnymi. W tym kontekście zrozumienie, że las jest wartością autoteliczną, samą w sobie, skłania ludzi dojrzałych moralnie do działań chroniących tę wartość, ponieważ zakorzenienie i osobiste uwewnętrznienie tej wartości, a nie wymogi zewnętrzne skłaniają do konsekwentnie słusznych reakcji. W tym sensie internalizacja najbardziej ogranicza próby instrumentalizacji wartości o właściwościach dobra wspólnego, samoistnego, niezależnego. Bowiem „zaszczepienie w sobie jakiejkolwiek wartości obiektywnej [...] pociąga za sobą parcie do odwzorowania w pełni obiektywnej hierarchii" (Kunowski 2003: 50). Dlatego jeśli człowiek ma strzec lasu jako wartości w sensie obiektywnym, to najpierw las niejako powinien emanować z człowieka. Ekologiczne wartości przyswajamy, gdy wartościując, uczymy się je rozumieć. Gdy są zaś dla nas oczywiste i zrozumiałe - stają się bardzo silne w swym preskryptywnym wpływie na nasze postepowanie moralne, co jednoznacznie pogłębia kompetencje aksjologiczne.

Internalizacja jest preskryptywna, co oznacza, że nie można przyswojonego przez siebie nakazu powinności nie wykonać bez uszczerbku wewnętrznego. Wartość jest źródłem tego, co powinienem zrobić, a świadomość tego faktu nie pozwala mi zrobić inaczej, chyba że wbrew sobie. Anna Jedynak, pisząc o odpowiedzialności w wymiarze globalnym, zaznacza, że „w przypadku odpowiedzialności wewnętrznej [...] podmiot o wysokich standardach moralnych może kierować się indywidualnym imperatywem w obszarze «nadwyżki aksjologicznej», gdzie nie można formułować, ani tym bardziej egzekwować, norm ogólnie obowiązujących. Można jednak zapytać, czy taki imperatyw nie przeradza się w nakaz wydany samemu sobie. Być może tak jest w wypadku ćwiczenia silnej woli i konsekwencji w posłuszeństwie sobie samemu. Czy rzeczywiście można być normodawcą tylko dla siebie? Jeśli tak, to w ślad za aksjologiczną podstawą odpowiedzialności podąża i podstawa tetyczna. Czy też, przeciwnie, taki imperatyw jest odwoływalny, swobodniejszy i słabiej zobowiązujący niż generalne 
normy? Jeśli to $\mathrm{z}$ kolei jest prawdą, to podstawa aksjologiczna zachowuje swoistą autonomię w stosunku do tetycznej” (Jedynak 2008: 29). Autonomia owa, samodzielność myślowa i aksjologiczna, jest w takiej sytuacji zagwarantowana niezależnością od zewnętrznej presji, umiejętnością odpowiadania na wymagania uwewnętrznionej wartości, a nie przymusu wyłącznie tetycznego. Ochrona ekowartości ze względu na własne przekonanie moralne jest gwarantem długoterminowego zobowiązania i pełnej odpowiedzialności, czego nie można powiedzieć o realizacji obowiązków moralnych niezwiązanych z internalizacją i mających wyłącznie charakter powierzchownej moralności zasad. Zrozumienie jest $\mathrm{w}$ pewnym sensie procesem jednokierunkowym, nie można od-rozumieć pewnych treści, nie da się procesu internalizacji zmienić ponownie w błogą nieświadomość. Bezmyślnie i nieświadomie można odpowiadać na wymagania innych ludzi tak długo, jak długo pozostają one zgodne $\mathrm{z}$ oczekiwaniami; autonomia zaczyna się tam, gdzie kończy się strach przez sankcjami, a pojawia satysfakcja z decyzji podjętej pod wpływem czytelnej dla nas, oczywistej wartości. Gdy wartość ta ma charakter ekologiczny tym bardziej wiąże się z samoprzypilnowaniem ze względu na związek z kategorią dobra wspólnego. Ekowartość ma bowiem szczególny charakter w kontekście preskryptywnego charakteru samego procesu internalizacji. Zobowiązanie uwewnętrznionej wartości przekonuje człowieka do odpowiedzi ściśle określonych, precyzyjnie powiązanych $\mathrm{z}$ wartościa jako taką. Preskryptywnie obligują do odpowiadania zgodnego ze stopniem zrozumienia tego, czym jest ekowartość, co jest źródłem mojej odpowiedzialności. W ten sposób można powiedzieć, że las jest dla człowieka, o ile chodzi o usensawniające założenie, że chodzi o autoteliczną ważność tejże wartości.

\section{Zagadnienie wartości}

Z faktu obecności wartości i jej rozpoznania człowiek wie, jaka wiąże się z tym powinność - na tym polega normatywny status axia; jeżeli wartość została zinternalizowana, przyswojona, to nabiera ona charakteru powinnościowego, normatywnego, określającego to, co być powinno. Samo bycie wartości jest wystarczającym powodem, żeby uznać normę, skoro sami przyjęliśmy wartość jako ważną, uznaliśmy ją za taką, uwewnętrzniliśmy ją, uwalniając się tym samym od powierzchowności nakazu. Gdy wartości są źródłem wymagań, głos norm zdaje się potwierdzać pewne intuicje osobiste, ale autonomia decyzji zgodnej z poznaniem i zrozumieniem wartości niewspółmiernie bardziej przekonuje do działania moralnego, niż posłuch normy. Zwłaszcza, że „moralność jako spełnianie nakazów [...] nie stanowi też wystarczającej podstawy do skonstruowania sensu własnego indywidualnego życia" (Hudzik 1999: 35). Człowieka do wartości zmusić nie można, ale przyswojenie jej sobie uwrażliwia w sposób trwały, jak szczepionka, dzięki której na stałe zyskujemy umiejętność podejmowania decyzji moralnych powodowanych stopniem uwewnętrznienia wartości jako takiej. Wartościowanie oznacza rozwój moralny, jest „ustosunkowaniem się do obiektywnej sfery wartości. Aktualizacja tego wartościowania polega na introcepcji wartości, z którymi osobowość chce się utożsamić, lub do których chce się zbliżyć i upodobnić" (Kunowski 2003: 59). Zgadzam się ze spostrzeżeniem Stefana Pikusa, że „od kultury moralnej jednostki zależy jej stosunek do środowiska przyrodniczego, w którym żyje. Kultury jednostki nie można odrywać od jej moralności, a moralności od stosunku jednostki do ludzi i przyrody" (Pikus 1997: 71). I choć „między wartościami a postępowaniem nie ma stosunku, jaki zachodzi pomiędzy potrzebą a środkiem jej zaspokojenia, nie ma też stosunku przyczynowego jednoznacznie określonego, zdeterminowanego, jaki jest między bodźcem a reakcją" (Kunowski 2003: 46), to jednak jesteśmy odpowiedzialni za to, co oswoiliśmy, jak powiedziałby Antonie Saint-Exupéry. Oswojona wartość warunkuje sposób 
odpowiadania na wymagania tego oswojenia i wpływa na postępowanie, choć nie wprost. Jeśli przyswoiłem, uczyniłem swoją jakąś wartość, to jest ona przeze mnie oswojona i ponoszę za nią odpowiedzialność. Sama znajomość wartości ekologicznych wcale nie wpływa w oczywisty sposób na postępowanie moralne; chyba że założymy długofalowy, funkcyjny związek pomiędzy wartością a moralnym rozwojem własnym, opartym w dużej mierze na dojrzewaniu odpowiedzialności, której podstawowym warunkiem jest internalizacja aksjologiczna. Wszak „niewątpliwie każdy człowiek podlega uznanym przez siebie wartościom. One to stanowią wektory postępowania ludzkiego przez określenie swoistej «siatki poznawczej» rozstrzygającej o sposobie postrzegania rzeczywistości, dokonywaniu rozróżnień na rzeczy istotne i błahe. Określają one treść i strukturę postaw" (Gajda 1995: 15). Dlatego też, jak twierdzi Ewa Trzaskowska, „edukację ekologiczną należy przy tym traktować jako trwały proces zamierzony na całe ludzkie życie" (Trzaskowska 1992: 97). Jest bowiem ściśle sprzężony z rozwojem moralnym i to w kontekście „usensawiającego” etapu rozumienia, a nie wyłącznie znajomości, wiedzy jako zbioru informacji o wartościach.

\section{Zakończenie}

Powodem, dla którego zjawisko internalizacji odnoszę do kwestii ochrony ekowartości lasu, jest sposób rozumienia wartości w charakterze sedna tworzącego sens odpowiedzialnego postępowania moralnego współczesnego człowieka. „Odwołując się do Floriana Znanieckiego, który wprowadził termin «współczynnik humanistyczny», możemy tu wprowadzić określenie «współczynnik aksjologiczny» - wszystko, co ludzkie, dopełnione jest wartościami" (Gołaszewska 1987: 314). W sytuacji, gdy las stanowi wartość ważną i jako taka zostaje ona przyswojona, to preskryptywnie człowiek zobowiązany zostaje do odpowiedzialności, czyli zdolności do dawania swojej autonomicznej aksjologicznie odpowiedzi na wymagania wartości przez siebie rozpoznanej.
Internalizacja ekowartości rodzi odpowiedzialność względem niej i to długofalowo. Nie da się raczej podejmować decyzji sensownych aksjologicznie bez preskryptywizmu internalizacji. "Sens związany jest z kategorią rozumienia" (Hudzik 1999: 33), z wpływem, jaki wywiera wartość na postępowanie w sytuacji osobistego oswojenia aksjologicznego jej autotelicznego charakteru. To wartość jest sensotwórcza - a działania związane z ochroną tej wartości albo odnoszą się do jej autoteliczności, albo nie; dlatego właśnie w przeważającej większości człowiek chroni siebie w lesie, a nie las w sobie. Las to środowisko, które „nie jest więc aksjologicznie jałowe, nie jest nie ukształtowanym tworzywem, surowym materiałem, któremu dopiero ludzka inwencja i praca mogą przydać wartości" (Bonenberg 20oo: 33). Najważniejszy bowiem rodzaj pracy związany z ekowartościami opiera się na wewnętrznym wysiłku aksjologicznym, kiedy to internalizacja preskryptywnie przekonuje człowieka do odpowiedzialności moralnej za wartości uznane za autotelicznie ważne.

\section{Bibliografia}

Boneneberg M., 200o. Aksjologiczne problemy ekologii, w: Poznanie i doznanie. Eseje z estetyki ekologii, Gołaszewska M. (red.), Universitas, Kraków, 32-51.

Ciążela H., 2006, Problemy $i$ dylematy etyki odpowiedzialności globalnej, Wyd. APS im. Marii Grzegorzewskiej, Warszawa.

Frączek Z., 2002, Edukacja aksjologiczna wobec potrzeb wspótczesności, Wydawnictwo Uniwersytetu Rzeszowskiego, Rzeszów.

Gajda J., 1995, Wychowywać do prawdy?, Wydawnictwo Uniwersytetu Marii Curie-Skłodowskiej, Lublin.

Gołaszewska M., 1987, W poszukiwaniu porzadku świata, Nasza Księgarnia, Warszawa.

Hudzik J.P., 1999, Sens życia jako wartość w przestrzeni kultury wspótczesnej, w: Wartości i antywartości w kontekście przeobrażeń kultury współczesnej, Szkołut T. (red.), Wydawnictwo UMCS, Lublin, 27-4,2.

Jedynak A., 2008, Odpowiedzialność w globalnej wiosce,: Wydawnictwo Naukowe Semper, Warszawa. 
Konstańczak S., 2001, Internalizacja wartości moralnych, Pomorska Akademia Pedagogiczna, Słupsk.

Kunowski S., 2003, Wartości w procesie wychowania, Oficyna Wydawnicza Impuls, Kraków.

Pikus S., 1997, Moralne aspekty ochrony środowiska przyrodniczego, Wyższa Szkoła Pedagogiczna, Słupsk.

Stacewicz J., 1993, Pomiędzy społeczeństwem ekonomicznym a ekologicznym, Polska Akademia Nauk, Instytut Rozwoju Wsi i Rolnictwa, Warszawa.
Trzaskowska E., 1992, O potrzebie i formach edukacji ekologicznej, w: Humanizm ekologiczny. Jakiej filozofii potrzebuje ekologia. Ochrona przyrody a ochrona człowieka, Pawłowski L., Zięba S. (red.), Politechnika Lubelska, Lublin, 97-103.

Zięba S., 2002, Ekosystem leśny wartościa człowieka, IBL, EkoKUL, Lublin.

\title{
Prescriptive internalisation as an axiological fundament of meaning the forest as an eco-value
}

\begin{abstract}
Internalisation, i.e. incorporation of axiological contents, is concurrent with gaining skills of a higher moral standard. In this process, objective values became the source of responsibility. Internalisation of axiological requirements stemming from eco-values is the most effective type of obligation due to its prescriptive nature: it is impossible not to keep a promise made to oneself without experiencing the loss of the given value. In this context, the internalised eco-values prescriptively influence the person whose sense of responsibility becomes stronger as the value becomes further internalised. Therefore, the forest, as an example of an eco-value, takes on an absolute nature only when prescriptive internalisation occurs - i.e. when the source of moral obligation is not so much the ecological necessity but an autotelic value.
\end{abstract}

\section{Keywords}

value, eco-value, prescriptive internalisation, axiology 